\title{
SISTEM PENDUKUNG KEPUTUSAN PEMILIHAN INTERNET SERVICE PROVIDER TERBAIK DENGAN METODE ANALYTICAL HIERARCHY PROCESS
}

\author{
Siti Nurajizah ${ }^{1^{*}}$, Nila Alis Ambarwati ${ }^{2}$, Sri Muryani ${ }^{3}$ \\ ${ }^{1}$ Sistem Informasi, Universitas Bina Sarana Informatika \\ ${ }^{2}$ Sistem Informasi, STMIK Nusa Mandiri \\ ${ }^{3}$ Teknik Informatika, STMIK Nusa Mandiri \\ email:*siti.snz@bsi.ac.id
}

\begin{abstract}
Internet packages are very important for mobile users. Many Internet Service Providers (ISPs) or internet service providers can help facilitate users in accessing the internet. Each ISP has a competitive advantage to attract internet users. Consumers are required to be smart in choosing internet packages so that they do not harm themselves. Based on this, an appropriate method is needed to assist in the selection of effective internet packages. Decision support systems have a variety of methods and one of them is the Analytical Hierarchy Process (AHP) method and is tested with Expert Choice 11. The results of the calculation using AHP are ranking each alternative that is obtained by the most important alternative and widely used by consumers is Telkomsel (Simpati Flash) in terms of security criteria is the ability to block viruses \& spam.
\end{abstract}

Keywords: AHP; Decision Support Systems; Internet Service Provider

\begin{abstract}
Abstrak: Paket internet merupakan hal yang sangat penting bagi para pengguna handphone. Banyaknya Internet Service Provider (ISP) atau disebut dengan penyedia layanan internet dapat membantu memudahkan pengguna dalam mengakses internet. Setiap ISP memiliki keunggulan yang saling bersaing untuk menarik minat pengguna internet. Konsumen dituntut jeli dalam memilih paket internet agar tidak merugikan mereka sendiri. Berdasarkan hal tersebut, diperlukan sebuah metode yang tepat untuk membantu dalam pemilihan paket internet yang efektif. Sistem pendukung keputusan memiliki berbagai metode dan salah satunya adalah metode Analytical Hierarchy Process (AHP) dan diuji dengan Software Expert Choice 11. Hasil dari perhitungan dengan AHP adalah perangkingan setiap alternatif yaitu diperoleh alternatif yang paling penting dan banyak digunakan oleh konsumen adalah provider Telkomsel (Simpati Flash) ditinjau dari kriteria keamanan yaitu kemampuan memblokir virus \& spam.
\end{abstract}

Kata kunci: AHP; Internet Service Provider; Sistem Pendukung Keputusan

\section{PENDAHULUAN}

Teknologi informasi yang semakin berkembang pesat menjadikan setiap kebutuhan hidup dapat diperoleh dengan sangat mudah, cepat dan efisien[1]. Internet merupakan salah satu teknologi yang sangat pesat perkembangannya dan sudah merupakan simbol dari cara berkomunikasi secara bebas, tanpa dibatasi ruang, jarak dan waktu. Penggunaan internet semakin meningkat seiring dengan bertambahnya kebutuhan manusia dibidang teleko- 
DOI: https://doi.org/10.33330/jurteksi.v6i3.632

Available online at http://jurnal.stmikroyal.ac.id/index.php/jurteksi

munikasi dan informasi [2]. Akses internet saat ini sudah dapat dijangkau dengan mudah oleh setiap orang. Hal ini disebabkan oleh semakin maraknya layanan paket internet yang ditawarkan para provider.[3]

Internet Service Provider adalah perusahaan yeng menyediakan jasa internet. Jaringan yang tersedia pada ISP terdiri dari jaringan berskala regional serta jaringan internasional yang menyebabkan para pelanggan dapat dengan mudah terkoneksi dengan dunia luar secara global. Banyaknya ISP yang tersedia tentunya memiliki karakterisktik yang berbeda-beda baik dari segi kualitas jaringan, bandwitch, perawatan pelayanan, stabilitas koneksi, serta harga yang ditawarkan[4].

Beragam pilihan provider sudah banyak termunculan saat ini. Para pendiri perusahaan provider harus dapat melihat dengan cermat tingkah laku konsumen[5] Setiap provider memiliki beragam karateristik kualitas. Setiap konsumen akan menetukan pilihan provider yang digunakan sesuai dengan kebutuhannya. Contohnya provider dengan kualitas baik tetapi memiliki harga yang relatif mahal, adapula provider dengan harga terjangkau tetapi terkendala dengan kestabilan koneksi internet[6]. Semua menawarkan beragam keunggulan yang membuat konsumen kesulitan dalam memilih provider yang tepat.

Sistem Pendukung Keputusan (SPK) merupakan suatu sistem informasi yang menghasilkan bermacam alternatif keputusan yang bertujuan membantu manajemen dalam menangani permasalahan secara terorganisir maupun tidak berdasarkan data dan model tertentu dan berdasarkan pendekatan kuantitatif dalam proses penentuan keputusan [7][8]. Sistem pendukung keputusan dipergunakan untuk membantu para pemegang keputusan seperti top manajeman dalam perusahaan untuk dapat mengambil keputusan dengan tepat berdasarkan hasil perhitungan yang matang[9].

Penggunaan sistem pendukung keputusan berlandaskan pada beragam kriteria dalam memilih hal terbaik sehingga diharapkan dapat menghasilkan sebuah keputusan dari beberapa alternatif yang diajukan[10]. Penelitian ini diharapkan dapat membantu konsumen dalam memilih provider terbaik.

\section{METODE}

Penelitian ini menggunakan metode Analytical Hierarchy Process menjadi alternatif penyelesaian terhadap pendukung keputusan pemilihan ISP terbaik. Penelitian ini dilaksanakan di wilayah RT 03 RW 03 Jatimulya, Bekasi. Dalam pembobotan kriteria pada metode AHP, bobot dari setiap kriteria ditentukan dengan memakai rumus dari metode AHP ini berdasarkan skala prioritas (tingkat kepentingan) yang bersumber dari tabel saaty [11]. Proses pengukuran dalam penelitian ini menggunakan kuesioner yang terdiri dari dua bagian, yaitu bagian pertama berisi tentang data pribadi responden sedangkan bagian kedua berisi tentang faktor yang mempengaruhi konsumen dalam memilih suatu provider internet.

Cara kerja metode AHP yaitu dengan menyelesaikan matriks bobot kriteria diawal, kemudian berlanjut pada alternatifnya[11]. Ciri khas dari metode AHP dapat terlihat pada penentuan bobot kriteria (Wj) berdasarkan hasil evaluasi matriks bobot kriteria bukan ditentukan di awal sepeti metode lainnya. Struktur 
dari metode HP dapat terlihat pada gambar dibawah ini:

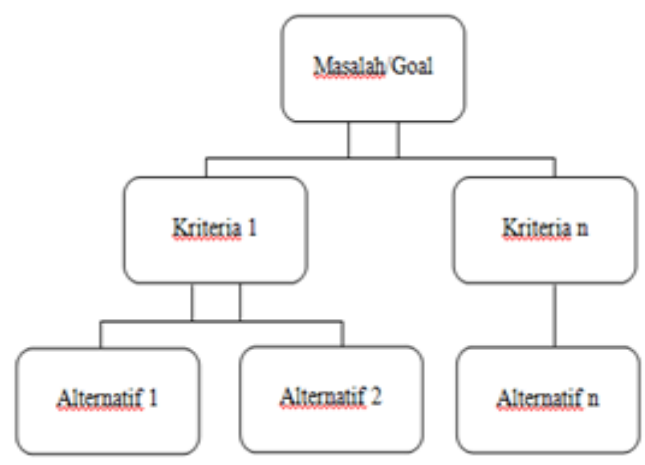

Gambar 1 Struktur Metode AHP

Berikut ini adalah langkahlangkah dalam metode AHP :

1. Menyusun Hirarki dari Permasalahan yang Dihadapi.

Persoalan yang akan diselesaikan secara terstruktur akan diuraikan menjadi unsur-unsurnya, yaitu kriteria dan alternatif, kemudian disusun menjadi struktur hirarki.

2. Penilaian Kriteria dan Alternatif

Kriteria dan alternatif dinilai melalui perbandingan berpasangan. Menurut Saaty, untuk berbagai persoalan, skala 1 sampai 9 adalah skala terbaik dalam mengeksprsikan pendapat. Nilai dan definisi pendapat kualitatif dari skala perbandingan, bisa diukur menggunakan tabel analisis seperti ditunjukkan pada tabel 1 .

3. Penentuan Prioritas

Untuk setiap kriteria dan alternatif, perlu dilakukan perbandingan berpasangan (pairwise comparisons). Nilainilai perbandingan relatif kemudian diolah untuk menentukan peringkat alternatif dari seluruh alternatif.

4. Konsitensi Logis

Semua elemen dikelompokkan secara logis dan diperingatkan secara konsisten sesuai dengan suatu kriteria yang logis. Matrix bobot yang diperoleh dari hasil perbandingan secara berpasangan tersebut harus tidak konsisten sempurna.

Tabel 2 merupakan berpasangan. Skala 1-9 adalah skala terbaik untuk mengekspresikan pendapat dari para pakar. Selain itu juga merupakan nilai definisi pendapat kualitatif.

Tabel 1 Skala Perbandingan Berpasangan

\begin{tabular}{|c|c|c|}
\hline $\begin{array}{c}\text { Tingkat } \\
\text { Kepentingan }\end{array}$ & Definisi & Keterangan \\
\hline 1 & $\begin{array}{l}\text { Sama Penting (equally } \\
\text { importance) }\end{array}$ & $\begin{array}{l}\text { Kedua elemen mempunyai pengaruh yang } \\
\text { sama. }\end{array}$ \\
\hline 3 & $\begin{array}{l}\text { Moderat lebih penting } \\
\text { (slightly more } \\
\text { importance) }\end{array}$ & $\begin{array}{l}\text { Elemen yang pertama memiliki preferensi } \\
\text { sedikit lebih tinggi dibandingkan elemen yang } \\
\text { kedua. }\end{array}$ \\
\hline 5 & $\begin{array}{l}\text { Lebih penting (materially } \\
\text { more importance) }\end{array}$ & $\begin{array}{l}\text { Elemen yang pertama memiliki preferensi } \\
\text { lebih tinggi dibandingkan elemen yang kedua. }\end{array}$ \\
\hline 7 & $\begin{array}{l}\text { Sangat lebih penting } \\
\text { (significantly more } \\
\text { importance) }\end{array}$ & $\begin{array}{l}\text { Elemen yang pertama memiliki preferensi jelas } \\
\text { lebih tinggi dibandingkan elemen yang kedua. }\end{array}$ \\
\hline 9 & $\begin{array}{l}\text { Mutlak lebih penting } \\
\text { (absolutely more } \\
\text { importance) }\end{array}$ & $\begin{array}{l}\text { Elemen yang pertama memiliki preferensi } \\
\text { mutlak lebih tinggi dibandingkan elemen yang } \\
\text { kedua. }\end{array}$ \\
\hline $2,4,6,8$ & & $\begin{array}{l}\text { Diberikan bila terdapat penilaian antara dua } \\
\text { penilaian yang terdekat. }\end{array}$ \\
\hline Kebalikan & \multicolumn{2}{|c|}{$\begin{array}{l}\text { Jika untuk aktivitas ke- } i \text { mendapatkan satu angka bila dibandingkan dengan } \\
\text { aktivitas ke-j, maka } j \text { memiliki nilai kebalikannya bila dibandingkan dengan } \\
i \text {. }\end{array}$} \\
\hline
\end{tabular}


DOI: https://doi.org/10.33330/jurteksi.v6i3.632

Available online at http://jurnal.stmikroyal.ac.id/index.php/jurteksi

Tabel 2 Nilai Random Index

\begin{tabular}{cc}
\hline $\begin{array}{c}\text { Ukuran } \\
\text { Matriks }\end{array}$ & $\begin{array}{c}\text { Nilai } \\
\text { RI }\end{array}$ \\
\hline $\mathbf{1 , 2}$ & 0,00 \\
$\mathbf{3}$ & 0,58 \\
$\mathbf{4}$ & 0,90 \\
$\mathbf{5}$ & 1,12 \\
$\mathbf{6}$ & 1,24 \\
$\mathbf{7}$ & 1,32 \\
$\mathbf{8}$ & 1,41 \\
$\mathbf{9}$ & 1,45 \\
$\mathbf{1 0}$ & 1,49 \\
$\mathbf{1 1}$ & 1,51 \\
$\mathbf{1 2}$ & 1,48 \\
$\mathbf{1 3}$ & 1,56 \\
$\mathbf{1 4}$ & 1,57 \\
$\mathbf{1 5}$ & 1,59 \\
\hline
\end{tabular}

Tabel 2 memperlihatkan nilai RI untuk setiap $\mathrm{n}$ objek. Memeriksa konsistensi hirarki. Adapun yang diukur dalam Analytical hierarchy process adalah rasio konsistensi dengan melihat index konsistensi. Konsistensi yang diharapkan adalah yang mendekati sempurna agar menghasilkan keputusan yang mendekati valid. Walaupun sulit untuk mencapai yang sempurna, rasio konsistensi diharapkan kurang dari atau sama dengan $10 \%$. Rumus untuk menentukan Indeks Konsistensi (CI) Indeks Konsistensi dari matrik berordo $\mathrm{n}$ dapat diperoleh dengan rumus:

$$
\mathrm{CI}=\frac{\lambda \text { maksimum }-}{\mathrm{n}-1} \text { (1) }
$$

$\Lambda$ maksimum didapat dengan menjumlahkan hasil perkalian jumlah kolom dengan eigen vector utama. Apabila C. $1=0$, berarti matrik konsisten. Batas ketidakkonsistensi yang diukur menggunakan rasio konsistensi (CR), yakni perbandingan index konsistensi dengan nilai pembangkit random (RI). Nilai RI bergantung pada ordo matrik $n$.
Adapun rumus untuk $\mathrm{CR}$ adalah:

$$
\mathrm{CR}=\frac{\mathrm{CI}}{\mathrm{RI}}
$$

Penjelasan lebih detail terkait tahapan dari Analytical Hierarchy Process adalah sebagai berikut [12]

1. Mendefinisikan masalah dan menentukan solusi yang diinginkan Dalam tahap ini penulis menentukan masalah yang akan dipecahkan secara jelas, detail dan mudah dipahami. Dari masalah yang ada penulis coba tentukan solusi yang mungkin cocok bagi masalah tersebut. Solusi dari masalah mungkin berjumlah lebih dari satu. Solusi tersebut nantinya penulis kembangkan lebih lanjut dalam tahap berikutnya.

2. Membuat struktur hirarki yang diawali dengan tujuan utama.

Setelah menyusun tujuan utama sebagai level teratas akan disusun level hirarki yang berada di bawahnya yaitu kriteria-kriteria yang cocok untuk mempertimbangkan atau menilai alternatif yang penulis berikan dan menentukan alternatif tersebut. Tiap kriteria mempunyai intensitas yang berbeda-beda. Hirarki dilanjutkan dengan subkriteria (jika mungkin diperlukan).

3. Membuat matrik perbandingan berpasangan

Matrik perbandingan berpasangan meng-gambarkan kontribusi relatif atau pengaruh setiap elemen terhadap tujuan atau kriteria yang setingkat di atasnya. Matrik yang digunakan bersifat seder-hana, memiliki kedudukan kuat untuk kerangka konsistensi, mendapatkan informasi lain yang mungkin dibutuhkan dengan semua 
perbandingan yang mungkin dan mampu menganalisis kepekaan prioritas secara keseluruhan untuk perubahan pertimbangan.

4. Mendefinisikan perbandingan berpasangan

Mendefinisikan perbandingan berpasa-ngan dilakukan sehingga diperoleh jumlah penilaian seluruhnya sebanyak n x [(n-1)/2] buah, dengan $\mathrm{n}$ adalah banyaknya elemen yang dibandingkan. Hasil perbandingan dari masing-masing elemen akan berupa angka dari 1 s.d 9 yang menunjukkan perbandingan tingkat kepentingan suatu elemen. Apabila suatu elemen dalam matrik dibandingkan de-ngan dirinya sendiri maka hasil perbandingan diberi nilai 1 . Skala 9 telah terbukti dapat diterima dan bias membedakan intensitas antar elemen. Hasil perbandingan tersebut diisikan pada sel yang bersesuaian dengan elemen yang dibandingkan.

5. Menghitung nilai eigen dan menguji konsistensinya. Jika tidak konsisten maka pengambilan data diulangi

6. Mengulangi langkah 3,4, dan 5 untuk seluruh tingkat hirarki.

7. Menghitung vector eigen dari setiap matriks perbandingan berpasangan. Menghitung vector eigin yang merupakan bobot setiap elemen untuk penentuan prioritas elemen-elemen pada tingkat hirarki terendah sampai mencapai tujuan.

8. Memeriksa konsistensi hirarki.

Dalam metode AHP yang diukur adalah rasio konsistensi dengan melihat index konsistensi. Konsistensi yang diharapkan adalah yang mendekati sempurna agar menghasilkan keputusan yang mendekati valid. Walaupun sulit untuk mencapai yang sempurna, rasio konsistensi diharapkan kurang dari atau sama dengan 10 $\%$.

Dalam penelitian ini terdapat tahapan penelitian yang bertujuan untuk mengolah data untuk menjawab rumusan masalah. Adapun langkah-langkah penelitian yang penulis lakukan menurut Arikunto didalam penelitian [13] yaitu :

1. Mengidentifikasi masalah

2. Merumuskan dan membatasi masalah

3. Melakukan studi kepustakaan

4. Merumuskan hipotesis atau pertanyaan penelitian

5. Menetukan desain dan metode penelitian

6. Menyusun instrumen dan mengumpulkan data

7. Menganalisis data dan menyajikan hasilnya

8. Menginterpretasikan temuan, membuat kesimpulan dan saran.

Sampel penelitian yang penulis gunakan sebanyak 10 responden, hal ini sesuai dengan penuturan Saaty(1993) dalam [14], yaitu metode AHP merupakan metode yang mengutamakan kualitas data dari responden bukan kuantitasnya. Jumlah responden yang digunakan dalam metode AHP tidak ada ketentuan khusus, dengan batas minimun dua orang responden.

\section{HASIL DAN PEMBAHASAN}

Pada penelitian ini penulis menggunakan 10 responden dalam pemilihan ISP Terbaik. Tabel dibawah ini merupakan alternative, yang mana alternative tersebut merupakan pilihan (choice). 
DOI: https://doi.org/10.33330/jurteksi.v6i3.632

Available online at http://jurnal.stmikroyal.ac.id/index.php/jurteksi

Tabel 3 Alternative ISP

\begin{tabular}{cc}
\hline Alternative & $\begin{array}{c}\text { Nama } \\
\text { Alternative }\end{array}$ \\
\hline A1 & Telkomsel (Flash) \\
A2 & Indosat IM3 \\
& Ooredoo (Internet \\
& Freedom) \\
A3 & XL Axiata (Paket \\
& Combo XTRA) \\
A4 & Tri (Kuota ++) \\
A5 & Axis (Paket \\
& BRONET) \\
\hline Tahapan & setelah dilakukan \\
pengolahan data adalah melihat apakah \\
rasio inkonsistensi lebih kecil atau sama \\
dengan 0,1. Jika rasio inkonsistensi lebih
\end{tabular}

besar dari 0,1 maka hasil akhir dari pengolahan tidak valid, harus dilakukan survey ulang.

Dari tabel 4 dapat ditarik kesimpulan bahwa perbandingan yang diberikan oleh responden memiliki nilai rasio inkonsistensi yang lebih kecil dari 0,1 . Dengan demikian kesimpulannya adalah hasil perbandingan yang dimiliki konsisten.Pada bagian ini tidak lagi memuat rancangan penelitian, namun terfocus pada hasil penelitian yang telah dilaksanakan.

Tabel 4. Perbandingan elemen dan nilai CR

\begin{tabular}{|c|c|c|}
\hline $\mathrm{NO}$ & Matriks Perbandingan Elemen & $\begin{array}{c}\text { Nilai } \\
\text { CR }\end{array}$ \\
\hline 1 & Perbandingan elemen antar criteria & 0,03 \\
\hline 2 & Perbandingan elemen antar sub kriteria pada kriteria biaya & 0,00 \\
\hline 3 & Perbandingan elemen antar sub kriteria pada kriteria tingkatan jaringan & 0,03 \\
\hline 4 & $\begin{array}{l}\text { Perbandingan elemen antar sub kriteria pada kriteria kemudahan } \\
\text { pengguna }\end{array}$ & 0,00 \\
\hline 5 & Perbandingan elemen antar sub kriteria pada kriteria keamanan & 0,00 \\
\hline 6 & Perbandingan elemen sub kriteria sistem prabayar pada kriteria biaya & 0,01 \\
\hline 7 & $\begin{array}{l}\text { Perbandingan elemen sub kriteria sistem pasca bayar pada kriteria } \\
\text { biaya }\end{array}$ & 0,04 \\
\hline 8 & $\begin{array}{l}\text { Perbandingan elemen sub kriteria EDGE pada kriteria tingkatan } \\
\text { jaringan }\end{array}$ & 0,02 \\
\hline 9 & $\begin{array}{l}\text { Perbandingan elemen sub kriteria GPRS pada kriteria tingkatan } \\
\text { jaringan }\end{array}$ & 0,03 \\
\hline 10 & Perbandingan elemen sub kriteria 3G pada kriteria tingkatan jaringan & 0,03 \\
\hline 11 & Perbandingan elemen sub kriteria 4G pada kriteria tingkatan jaringan & 0,02 \\
\hline 12 & $\begin{array}{l}\text { Perbandingan elemen sub kriteria aktivasi layanan pada kriteria } \\
\text { kemudahan pengguna }\end{array}$ & 0,02 \\
\hline 13 & $\begin{array}{l}\text { Perbandingan elemen sub kriteria jangkauan jaringan pada kriteria } \\
\text { kemudahan pengguna }\end{array}$ & 0,03 \\
\hline 14 & $\begin{array}{l}\text { Perbandingan elemen sub kriteria kemampuan memblokir situs tertentu } \\
\text { pada kriteria keamanan }\end{array}$ & 0,04 \\
\hline 15 & $\begin{array}{l}\text { Perbandingan elemen sub kriteria kemampuan memblokir virus \& } \\
\text { spam pada kriteria keamanan }\end{array}$ & 0,06 \\
\hline
\end{tabular}


DOI: https://doi.org/10.33330/jurteksi.v6i3.632

Available online at http://jurnal.stmikroyal.ac.id/index.php/jurteksi

\begin{tabular}{ccc}
\multicolumn{3}{c}{ Tabel 5 Perangkingan Kasus Metode AHP } \\
\hline No & Provider & Keterangan \\
\hline 1 & Telkomsel (Simpati Flash) & Rangking 1 \\
2 & Indosat IM3 Ooredoo (Internet Freedom) & Rangking 5 \\
3 & XL Axiata (Paket Combo XTRA) & Rangking 2 \\
4 & Tri (Kuota ++) & Rangking 3 \\
5 & Axis (Paket Bronet) & Rangking 4
\end{tabular}

Tabel 5 menunjukkan bahwa alternatif yang direkomendasikan secara berurutan adalah: 1). Telkomsel (Simpati Flash), 2). XL Axiata (Paket Combo XTRA), 3). Tri (Kuota ++), 4). Axis (Paket Bronet), 5). Indosat IM3 Ooredoo (Internet Freedom).

\section{SIMPULAN}

Berdasarkan hasil dan pembahasan pada penelitian ini dapat ditarik kesimpulan bahwa metode AHP dapat membantu dalam pemilihan ISP Terbaik dengan menentukan kriteria utama dari beberapa kriteria serta alternatif yang ada untuk pendukung keputusan. Metode AHP dapat menentukan alternatif pemilihan ISP Terbaik dengan hasil akhir ISP terbaik adalah Telkomsel (Simpati Flash).

\section{DAFTAR PUSTAKA}

[1] Z. Azhar, "Penentuan Penempatan Karyawan Baru Di PDAM Kisaran Dengan Metode SMART," JURTEKSI (Jurnal Teknol. dan Sist. Informasi), vol. Vol.4, no. 1, pp. 179-184, 2018.

[2] F. S. Medyati, M. Aritonang, and S. W. Rizki, "Analisis Laik Fungsi Jalan Nasional Batas Kota Sigli Beureunuen Menggunakan Metode Analytic Hierarchy Process," Bimaster, vol. 08, no. 3, pp. 563-572, 2019.

[3] Y. Prihartono and H. Magdalena, "Penerapan Metode Analytical Hierarchy Process (AHP) Sebagai Pendukung Keputusan dalam Menentukan Internet Service Provider Terbaik di Pangkalpinang," J. Sisfokom (Sistem Inf. dan Komputer), vol. 5, no. 1, p. 21, 2016.

[4] I. Dahanum, Mesran, and T. Zebua, "Sistem Pendukung Keputusan Pemilihan Internet Service Provider Menerapkan Metode Elimination and Choice Translation Reality ( Electre )," Konf. Nas. Teknol. Inf. dan Komput., vol. I, no. November, pp. 248-255, 2017.

[5] E. Suhartono, "Penentuan Pemilihan Operator Seluler Dengan Metode Analisis Efektifitas," MAKSIPRENEUR, vol. VI, no. 2, pp. 18-26, 2017.

[6] D. Kurniawan, W. Wardhana, and N. A. Ito, "Penggabungan Dua ISP Guna Menstabilkan Koneksi Internet Dengan Metode Failover," J. Komputasi, vol. 4, no. 2, pp. 111, 2016.

[7] F. Sari, Metode Dalam Pengambilan Keputusan. Yogyakarta: CV Budi Utama, 2017.

[8] S. Andriyani and F. M. Yuma, "Kombinasi Metode Analitical Hierarchy Process Dan Weighted Product Dalam Penentuan Benih 
Cabai Unggul," J. Teknol. dan Sist. Inf., vol. 6, no. 2, pp. 117124, 2020.

[9] Haryani and D. Fitriani, "Sistem Pendukung Keputusan Penentuan Karyawan Terbaik Pada Collection Pt . Panin Bank Menggunakan," J. Mantik Penusa, vol. 3, no. 1, pp. $1-8,2019$.

[10] R. Amin, "Metode Analytical Hierarchy Process Dalam Sistem Pendukung Keputusan Pemilihan Internet Service Provider," J. Tek. Komput., vol. 1, no. 1, ISSN 2442/2436, pp. 66-71, 2015.

[11] D. Nofriansyah and S. Defit, Multi Criteria Decision Making
(MCDM) pada Sistem Pendukung Keputusan. Yogyakarta: CV Budi Utama, 2017.

[12] A. Basuki and C. Dwi, Sistem Pendukung Keputusan. Yogyakarta: CV Budi Utama, 2016.

[13] Sudaryono, Metode Penelitian. Depok: PT Raja Grafindo Persada, 2017.

[14] T. Zulhadi, S. M. Saleh, and R. Anggraini, "Analisis Laik Fungsi Jalan Nasional Batas Kota Sigli Beureunuen Menggunakan Metode Analytic Hierarchy Process," J. Tek. Sipil, vol. 1, no. September, pp. 251-262, 2017. 